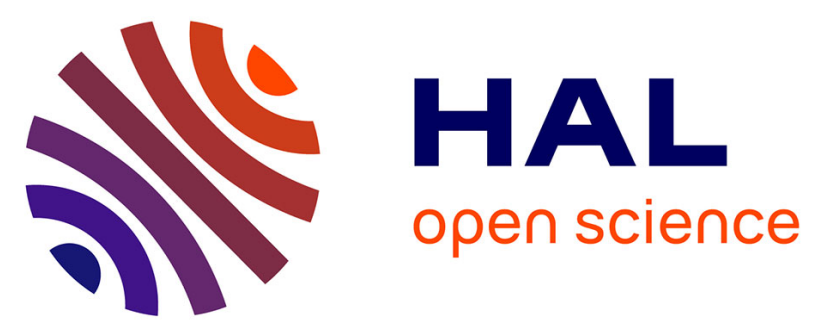

\title{
Should Voting Be Compulsory? Democracy and the Ethics of Voting
}

Annabelle Lever, Alexandru Volacu

\section{To cite this version:}

Annabelle Lever, Alexandru Volacu. Should Voting Be Compulsory? Democracy and the Ethics of Voting. Annabelle Lever; Andrei Poama. The Routledge Handbook of Ethics and Public Policy, Routledge, pp.242 - 254, 2018, 9781138201279. hal-02506504

\section{HAL Id: hal-02506504 \\ https://hal-sciencespo.archives-ouvertes.fr/hal-02506504}

Submitted on 12 Mar 2020

HAL is a multi-disciplinary open access archive for the deposit and dissemination of scientific research documents, whether they are published or not. The documents may come from teaching and research institutions in France or abroad, or from public or private research centers.
L'archive ouverte pluridisciplinaire $\mathbf{H A L}$, est destinée au dépôt et à la diffusion de documents scientifiques de niveau recherche, publiés ou non, émanant des établissements d'enseignement et de recherche français ou étrangers, des laboratoires publics ou privés. 


\title{
Should Voting Be Compulsory? Democracy and the Ethics of Voting
}

\author{
Annabelle Lever and Alexandru Volacu \\ The Routledge Handbook of Ethics and Public Policy (2018) \\ Eds. Annabelle Lever and Andrei Poama
}

Ch. 19, pp. $242-254$

\begin{abstract}
The ethics of voting is a new field of academic research, uniting debates in ethics and public policy, democratic theory and more empirical studies of politics. A central question in this emerging field is whether or not voters should be legally required to vote. This chapter examines different arguments on behalf of compulsory voting, arguing that these do not generally succeed, although compulsory voting might be justified in certain special cases. However, adequately specifying the forms of voluntary voting that are consistent with democratic norms is likely to be philosophically complex and politically controversial.
\end{abstract}

The ethics of voting may seem a strange subject for a book on ethics and public policy. After all, one might think, once the state has ensured that all competent adults have legal rights to vote, is not the rest up to the conscience of voters? This intuitive way of thinking, however, ignores the way that the rules of voting are likely to reflect factual and normative assumptions about voters' behaviour, and may, in turn, affect what voters do. For example, many more people are likely to attend the polls if voting takes place at the weekend, rather 
than during the working week (Ballinger 2006, 20) and proportional representation is thought to boost turnout by $12 \%$ (Margetts 2006, 29). Indeed, the differences amongst proportional systems affects the extent to which voters are encouraged to vote on local, as opposed to national, considerations, or to base their votes on strategic, as opposed to sincere, preferences. It is therefore difficult sharply to distinguish the questions of whether and/or how people should vote, given the rules in place, from the question of what those framing rules should be. ${ }^{1}$

Any normative evaluation of voting rules, and the moral duties that citizens have in respect to voting, therefore, cannot help but involve discussions on the nature and value of democracy. This becomes apparent when one considers contemporary debates about the politics and morality of compulsory voting. Compulsory Voting (hereafter, 'CV') is often thought to be undemocratic because it imposes legal penalties on those who do not attend the polls at election time. However, there are many examples of $\mathrm{CV}$ in consolidated democracies such as Australia (since 1924), Belgium (since 1893), Luxembourg (since 1919) or the Netherlands (between 1917 and 1967). In Latin America, CV has been an enduring electoral institution, even though it was introduced at an early stage of democratization (as is the case of Bolivia and Uruguay) or during periods when the military exerted significant political power (as is the case of Brazil, Chile, Ecuador and Peru). Moreover, its use has been energetically advocated by academics, and 'think tanks' (Wertheimer 1975; Lijphart 1997; Hill 2002; Keaney and Rogers 2006; Birch 2009a and 2009b; Tin and Wieviorka 2011²) and even politicians such as Barrack Obama ${ }^{3}$ or Geoffrey Hoon ${ }^{4}$. Thus, examining the arguments for and against the idea that $\mathrm{CV}$ is compatible with, and even necessary for, democracy enables us to investigate contemporary debates on the ethics of voting and their relationship to democratic principles and practice. 
Democratic principles limit the ways we can evaluate competing arguments for CV. For example, democratic principles limit moralistic and paternalistic actions by the state, in the interests of protecting people's freedom and equality (J. Cohen 1996). They therefore limit the extent to which people can be forced to vote on moralistic or paternalistic grounds (Lever 2008; Maring 2016; Maskivker 2016). Democratic principles also constrain the arguments we can give against $\mathrm{CV}$, because some forms of voluntary voting are incompatible with democratic ideas about what it is to treat people as free and equal. For example, we can imagine a system of voluntary voting in which citizens have to organise elections themselves, and take responsibility for ensuring that elections are fair, without any help from the state in doing so, as though democratic elections were simply a private good, important only to the people who participate in them, but with no claim to support by anyone else. Voluntary voting, then, is not intrinsically democratic. Nonetheless, this chapter shows, CV is generally at odds with democratic principles - whether we look at democracies in more idealistic, or more realistic ways (Estlund 2008, 258-275). However, in unusual circumstances, CV may, perhaps, be justified.

Let's start by examining the case for CV as it is presented by Arend Lijphart, in his Presidential address to the American Political Association, published in the American Political Science Review (Lijphart 1997). This article sparked the current interest in compulsory voting, and its strengths and weaknesses make it a particularly helpful guide to the political, as well as the moral, dimensions of voting.

\section{Lijphart's argument for CV}

Lijphart's case for compulsory voting can be summarised in the following 4 steps. 
(1) Low turnout at election-time is a pervasive problem in most advanced democracies, and low turnout is associated with unequal turnout, because social groups do not abstain at the same rate (Lijphart 1997, 2-7). For example, the participation gap between manual and nonmanual workers in Great Britain more than doubled: from around 5\% in 1997 to around 11\% in 2005. These results are not dissimilar in other countries (Birch 2009b). Moreover, as Ballinger notes, non-voting is now more common than voting in the 18-24 age group in the UK' (Ballinger 2006, 14; Keaney and Rogers 2006, 11; more generally see Blais 2000, 4954).

Low turnout is a concern for democracies, because it increases the probability that governments will be elected by a minority of the population - sometimes, by a very small minority of the population - thereby compromising the claims of governments to represent most people, and to be entitled to govern in their name. Unequal turnout is a concern, because it suggests that some groups - in particular, low-skilled workers and youngsters - are alienated from electoral politics in ways that cast doubt on the substantive fairness of electoral arrangements, and the representative character of government, however perfect they appear at first sight (Keaney and Rogers 2006; Lacroix 2007; Birch 2009b). Hence, concerns for the legitimacy, fairness and stability of democratic government motivate Lijphart's case for compulsion. As Lijphart summarises the point, a 'crucially important reason to aim for maximum turnout is democratic legitimacy' (1997, 2, footnote 2).

(2) While there are several potential cures for low turnout - such as weekend voting and proportional representation- Lijphart notes that none is as immediate and as successful at tackling both low and unequal turnout as CV (Lijphart 1997, 7-10; Birch 2009b; Hill 2006, 210-212).

(3) According to Lijphart, it would be inconsistent with democratic principles to force voters to choose amongst candidates. However, he thinks, there is nothing immoral with forcing 
people to present themselves at the polls, and to tick off their names from a list, even if they do not wish to vote. 'Compulsory voting', on his view, should therefore be understood as 'compulsory turnout' - as it was practiced in the Netherlands between 1917 and 1967 (Gratschew 2004).

Given this understanding of $\mathrm{CV}$ as $\mathrm{CT}$, it is surprising that Australia's apparently spectacular figures for electoral participation figure in arguments for compulsory turnout such as Lijphart's. Australia legally requires all registered voters to vote, unless granted a conscientious exemption - the terms of which are never made public (Hill 2002, 442-448; Ballinger 2006, 8 footnotes 18-19). Australia's form of compulsory voting is therefore inconsistent with freedom of conscience, as contemporary proponents of CV generally understand it, and appears, unfortunately, to assume that secular objections to voting cannot be conscientious. It would therefore be best to set the Australian case to one side when evaluating democratic arguments for compulsory voting, given that key features of Australian practice seem inconsistent with democratic principles. ${ }^{5}$

(4) Finally, Lijphart argues that non-voters can be treated as free-riders, because they get the benefits of democratic elections, such as peaceful changes of power, and legitimate governments bound by norms of freedom and equality, but without making the effort to decide which of the available candidates for electoral office merits their support (Lijphart 1997, 11; Wertheimer 1975; Engelen 2007; Lacroix 2007). While it may be individually rational for each of us not to vote, and to leave others to do so, such behaviour is unfair, according to Lijphart and, if sufficiently widespread, can undermine the legitimacy of democratic government. Hence, he believes, compulsory voting is justified because no morally or politically significant liberties are threatened by a legal obligation to 'turnout', and the increases in voting, which compulsory turnout creates, can significantly remove the twin problems of low and unequal turnout. 
Lijphart's arguments for compulsory voting are self-consciously democratic, reflecting the idea that legal compulsion can protect rather than undermine people's freedom, by combatting predictable failures of judgement and of will (Lacroix 2007; Engelen 2007; Satz 2010). Likewise, his assumptions about equality are self-consciously democratic, although few philosophers are likely to accept Lijphart's idea that treating people as equals always requires us to designate legal ceilings and floors which limit the ways in which people can differ (Lijphart 1997, 2; Young 1990; Bardon and Ceva in this volume).

Finally, what makes Lijphart's article notable is that it presents, in particularly pure form, two very different conceptions of the relationship between the ethics of voting and the justification for a legal duty to vote. On the first, Lijphart's argument is explicitly egalitarian and social-democratic - concerned with the way that rights to abstain can make it hard to pass social-democratic or redistributive economic policies in contemporary democracies. On the second, Lijphart's argument is concerned with the way that compulsory voting might further collective goods that are important to all democratic citizens, whether or not they support explicitly egalitarian or social democratic forms of politics. Let's call the first argument the 'egalitarian' argument for $\mathrm{CV}$, and the second argument the 'fairness' argument for $\mathrm{CV}$. Contemporary proponents of compulsory voting tend to adopt one or both of these arguments, so their strengths and weaknesses can help us to evaluate the arguments in favour of compulsory voting.

\section{The egalitarian argument for $\mathrm{CV}$}

On the egalitarian argument, compulsory voting is justified in order to promote voting by those who do not vote and who, Lijphart assumes, would benefit from more egalitarian 
policies than are currently favoured by those who do. This first argument for compulsory voting, therefore, assumes that democratic politics can involve quite sharp conflicts of interests amongst social groups - for example, around redistributive economic policies. Nonvoters under voluntary voting, then, are likely to lose out in what is, in important respects, a zero-sum political game, although if they were forced to vote they might be expected to win, and to be capable of passing social-democratic policies, at least some of the time (Lijphart 1997, 4-5; see also Birch 2009a, 23; Hill 2006, 213-215).

However, unless the disadvantaged vote in a self-interested manner, when forced to vote, there will be no egalitarian case for CV on Lijphart's assumptions. Not-voting by the disadvantaged, and altruistic voting are, from an egalitarian perspective, merely two different ways whereby the disadvantaged may perpetuate their disadvantaged situation, faced with the behaviour of the advantaged. ${ }^{6}$ So, on the assumption that this disadvantage is unjust, and we need to remove it, the egalitarian argument for $\mathrm{CV}$ appears to assume that the disadvantaged are morally required, not just permitted, to vote on their self-interest.

But why suppose this? If the advantaged voted to alleviate disadvantage, there would be no egalitarian case for forcing the disadvantaged to participate electorally. ${ }^{7}$ Perhaps egalitarians should therefore try to change the dispositions and behaviour of voters, and politicians, rather than trying to force non-voters to go to the polls? Indeed, from an egalitarian perspective, the political logic of compulsory voting is poor, because it seeks to get everyone to vote whether or not they care about equality (Lever 2010a).

Morally, too, the egalitarian case for $\mathrm{CV}$ is unpersuasive, even if we treat it as a remedial response to selfish or thoughtless voting by the advantaged. There is no egalitarian case for $\mathrm{CV}$ unless the disadvantaged vote their self-interest, which, if their disadvantaged position is 
unjust, they are morally entitled to do. But it does not follow from the fact that it is morally permissible for them to vote on self-interested grounds, that it is morally obligatory to do so.

It is unlikely that the disadvantaged are morally required to treat the injustices from which they suffer as more important than other considerations (Shelby 2007). So, whether we look at the moral or the political dimensions of the egalitarian case for $\mathrm{CV}$, it is hard to see why legitimate concerns for injustice and inequality require forcing non-voters to vote, let alone to 'turn out' at election time.

We might try to save the egalitarian argument by saying: 'but the duty of the disadvantaged is to vote for justice, not for their self-interest. It is only because voting for their self-interest will alleviate injustice that they have a duty to vote on their self-interest'. But does justice require us to vote, regardless of the choices we face? Indeed, does justice require us to vote regardless of the likely behaviour of our fellow voters, or of the other ways in which we might promote justice? Indeed, should injustice to disadvantaged non-voters take precedence over other moral concerns at election time? The most likely answer to these questions is 'no'. Hence, it is unclear that democratic citizens generally have a duty to vote, even if it might improve their situation, and that of others like them. The egalitarian case for compulsion takes seriously the conflicts of interest which can characterise, and undermine, democratic politics - that is a great part of its appeal. Unfortunately, however, Lijphart's case for $\mathrm{CV}$ fails adequately to reflect the moral and political challenges posed by those conflicts of interest. 
It is therefore worth considering if a procedural case for $\mathrm{CV}$ can be developed that would reflect the strengths and weaknesses of Lijphart's consequentialist egalitarian argument. For example, Lisa Hill suggests that the differential effects of coordination problems might explain the phenomenon of low and unequal voting, and provide a justification for $\mathrm{CV}$, whether or not the disadvantaged vote on their self-interest (Hill 2006, 213-215; Hill 2010, 922-923; Birch, 2009, 23). According to Hill, high rates of turnout in and of themselves increase the chances of egalitarian social policies. ${ }^{8}$ Compulsory voting may therefore be justified on egalitarian grounds even if current non-voters vote in ways that are ignorant, random, and counter-productive (Caplan 2008).

What makes this argument procedural as well as egalitarian, is that $\mathrm{CV}$ is meant to respond to the unfair burdens on successful political action created by schemes of voluntary voting. Voluntary voting means that one is never sure whether or not one's political allies will vote and this uncertainty can affect one's likelihood of voting. Such assurance and coordination problems, Hill plausibly maintains, are more difficult for poor, than for rich, people to overcome (Brennan and Hill 2014, 147-152, esp. 151). Hence, while elections under voluntary voting laws look fair, in practice they create procedural injustices that predictably disadvantage poorer social groups.

Potential voters can be unfairly disadvantaged by apparently fair rules, as the procedurally egalitarian argument for $\mathrm{CV}$ maintains. For example, universal suffrage and majority rule may replicate, rather than remedy, morally arbitrary forms of power, because large, dispersed groups, such as consumers or workers, may find it harder to organise than smaller, more focused groups, such as producers and employers (Olson 1965). Likewise, freedoms of political association, expression and choice offer insufficient protection for the freedom and equality of members of historically disadvantaged ascriptive groups - such as women, the members of racialised minorities, indigenous groups, and the disabled (Phillips 1995; 
Williams 1998; Mansbridge 1999). However, these well-known examples of the unequal burdens created by apparently fair electoral rules appear to cross, rather than to track, the difference between non-voters and voters. It is therefore unclear that - or how- compulsory voting will remedy them. Indeed, CV may exacerbate injustice in so far as non-voting is a response to a competitive political system that looks fair, but isn't. ${ }^{9}$ Hence, the procedural arguments for compulsory voting on egalitarian grounds, which Hill and Birch try to develop, seem unlikely to circumvent the difficulties of more directly consequentialist arguments for CV.

\section{The Fairness Argument for CV}

The difficulties with the egalitarian argument for $\mathrm{CV}$ leave open the possibility that compulsory voting might be justified for reasons that are less intimately tied to facts about low and unequal turnout than Lijphart thought. Hence the interest of Lijphart's second argument for CV - what we have called the 'fairness' argument for compulsion. The idea here is that "nonvoting is a form $[\ldots]$ of free riding - and $[\ldots]$ free riding of any kind may be rational but is also selfish and immoral' (Lijphart 1997, 11). The appeal of this second argument for $\mathrm{CV}$ is obvious: if it works, it offers an argument for CV that anyone can accept, as long as they care about democracy. It is therefore independent of our political preferences, and of our views about how people ought to vote, or to behave more generally. It is irrelevant to the fairness argument whether the association between left-leaning politics and highturnout is as tight as Lijphart assumes; and it is irrelevant whether there are, in fact, other ways that might be as good at raising and equalising turnout, alone or in combination with other socio-political changes (Margetts 2006; Saunders 2010; Stone 2011; Lopez-Guerra, 
2014). The point of the fairness/collective goods argument is to combat free-riding (on the assumption that it is morally wrong), and not simply to improve turnout. It is therefore concerned with the assurance of fairness that legal compulsion can provide, and with the public affirmation of (supposedly) public duties.

The fairness argument for compulsory voting, however, is at odds with the egalitarian argument for compulsion, so it is difficult to insist on both as justifications for compulsion. On the egalitarian argument for $\mathrm{CV}$, non-voters are to be pitied and supported, because they are disadvantaged, marginalised and excluded by an unfair political system. On the fairness argument, by contrast, non-voters are parasites, preying on the collectively beneficial efforts of voters. Proponents of compulsion must therefore decide which picture of non-voters they believe to be closest to the truth. Likewise, on the egalitarian case for $\mathrm{CV}$, high-turnout is desirable for partisan reasons - because low turnout is likely to disadvantage parties of the left. By contrast, on the fairness argument for $\mathrm{CV}$, high-turnout is a sufficiently important public good that we are justified in forcing people to vote. Proponents of $\mathrm{CV}$, therefore, must also decide which of these strikes them as the most persuasive, given plausible ways of interpreting 'high' and 'low' turnout.

Democratic politics is a competitive as well as a cooperative affair (Lever 2010b, p.915). However, Lijphart's egalitarian case for CV focuses solely on the competitive aspects of democracy, whereas the fairness argument for CV focuses solely on the cooperative ones. But if the combination of shared and conflicting interests makes it possible for us to envisage political solutions to our problems, then to ignore the ways that people can have conflicting, but also shared, interests risks depoliticising their situation in ways that are likely to undermine, rather than support, democracy. Hence the difficulty with the portrayal of nonvoters and high turnout implied by the fairness argument for compulsion. 
If non-voters are to be persuasively viewed as free-riders, they must be trying unfairly to benefit from the cooperative efforts of others - as though they were trying to jump a queue for the bus. Even setting aside cases where people do not vote for conscientious reasons, or because they are unsure who to vote for, this picture of non-voters is problematic. If there is no candidate at election time who you trust, or whose programme you support, then your failure to vote is an expression of disappointment, disgust, alienation, exasperation - perhaps also of confusion and ignorance - but not of a willingness to take advantage of others. ${ }^{10}$

There are normative problems with the fairness argument too. People are clearly entitled to abstain for conscientious reasons and may sometimes be morally obliged to do so (Brennan 2009; Hanna 2009). Non-voting on such grounds cannot be equated with unfairness or exploitation. Moreover, even when people are morally wrong to abstain, and even when that wrong consists in harming others, ${ }^{11}$ it is odd to think of voters as the primary victims of harm (Lever, 2010b, 914). Rather, it seems that when non-voting harms others, the primary victims are those who are unable to vote to protect their own interests - the young, the old, the ill, and those who are foreign. Non-voting may also harm some voters by letting them down, or making it harder for them to realise their legitimate ends. But, even where this is so, these harms seem much less serious than those suffered by the voiceless and the voteless. So the fairness argument for CV seems to misrepresent the harm of abstention, when it is harmful, and wrongly to stigmatise behaviour that may not be morally wrong, or harmful, at all.

These problems arise because the fairness argument, as presently formulated, assumes that high turnout is democratically desirable, and a public good. It will be helpful, then, to look at the relationship between turnout and legitimacy more closely, and also to consider if it is possible to reformulate the fairness argument in order to avoid question-begging claims about the importance of high-turnout. 


\section{High-turnout and democratic legitimacy}

Current ways of describing turnout for the purposes of cross-national comparisons use country-specific rates of turnout at national elections as their basis. They therefore imply both that the frequency of elections, and their political importance are irrelevant to the ways we should classify elections as 'high' or 'low'. However, it is well-known that countries, such as the USA or Switzerland, have low rates of turnout at national elections, in part because they decide many more things electorally than other countries (Lijphart 1997, 8). Arguments for $\mathrm{CV}$, therefore, need to explain why we should lump countries like the USA and Switzerland into a category of 'low turnout' countries that includes Poland (a country with unusually low rates of voting at national elections), when citizens may be participating electorally to quite different extents.

Likewise, arguments for CV assume that rates of turnout should be measured and assessed irrespective of the interest and importance of the election in question, or of the ability of voters to remove incumbents. Indeed, countries which appeared to have low rates of turnout, such as the UK and the USA, may have voters who are remarkably willing to vote, once one takes into account the advantages of incumbency. ${ }^{12}$ In short, it is unclear that current ways of describing rates of turnout for cross-national purposes are adequately tracking morally and

politically significant differences amongst people's willingness to participate politically, or to support democracy (more generally, see Rovensky, especially 42-93).

\section{Low Turnout and Legitimacy}


But what of the idea that low turnout threatens democratic legitimacy? The reasons why highturnout can promote legitimacy reflect the idea that losers have reason to accept or 'consent' to an outcome that they did not want, because 'it was a fair fight' (Weale 1999, 195-200). If legitimacy comes from winning a fair fight, however, it is the fairness of the fight, not the level of turnout, that is critical to legitimacy (Brennan, 2016).

Even in non-ideal conditions, it is not evidently unfair that many of us have no chance of choosing a winning political coalition, or of being elected to political office, ourselves. Our views may be too idiosyncratic, speculative, or incoherent for us to form part of an electoral majority. As political professionals, or amateurs, we may lack political gifts, such as the gift of rhetoric, to which Walzer (1983) refers when arguing that some inequalities in politics are consistent with democratic government. We -and our favoured political candidates- may also lack the personality necessary for political success - being too impatient, or too accommodating for a given political climate, or a particular ideological context. As such we may have no reason to vote, while being willing to accept whoever is elected as legitimate, and willing to participate as amateurs in politics on occasion.

Injustice is neither a necessary nor a sufficient condition for low turnout in democratic politics, then. Politics is hard - often boring, frustrating, full of difficult things to learn, remember and apply; above all, it is time-consuming as democratic politics means persuading lots of people to support you, to trust you, and to make sacrifices for you with little, if any, external rewards (Weber 1919). Even following politics carefully, and being well-informed about it is likely to be distressing and unrewarding (compare Lijphart 1997, Lacroix 2007, Engelen 2007 and 2009 on the 'undemanding' nature of CV). This is not because politicians are especially duplicitous or incompetent, but because democratic politics is tough, and the 
ability to change the world for the better may seem dishearteningly small compared to the need for change. ${ }^{13}$

The fairness argument for $\mathrm{CV}$, then, will not work as long as it requires us to assume that high turnout is a public good, or necessary to democratic legitimacy. We could avoid this difficulty by frankly assuming that fairness requires us to vote for the common good and, therefore, to vote - absent compelling reasons to abstain. Although talk of a 'common good' has been condemned as populist and incoherent, (Riker 1982) or as impossible to reconcile with the diversity of democratic interests and beliefs, (Dahl 1989) the idea of a common good figures prominently in the literature on deliberative democracy, as well as in much contemporary liberal, republican, communitarian and cosmopolitan thought. Moreover, there is nothing especially peculiar about the idea that large groups of people might have interests in common - interests in peace, security, prosperity, wisdom, wellbeing - which are consistent with treating each other as political equals, and with taking seriously the moral claims of non-citizens. So, perhaps it is unfair not to vote for the common good, and it is this unfairness which, with generous exemptions for conscience and need, provides the best case for compulsory voting?

\section{Voting and the Common Good}

Citizens must bear the good of other citizens in mind while voting. It would be irresponsible and wrong not to do so, because our individual votes may contribute to the election of a government that will speak in our name, and that can bind us, domestically and internationally (Cohen 1996; Beerbohm 2012; Brennan 2016). However, it does not follow that we have a duty to maximise our common good, when voting, rather than to satisfice it. A 
duty to maximise our common good, after all, implies that nothing can be more important politically than advancing the ends we have in common. Such a position would be contentious even in ideal theory, and in non-ideal circumstances it seems deeply implausible, given that we may have urgent duties to remedy injustices inherited from the past at home and abroad (Lever 2017).

The familiar complaint that egalitarians may lack a reason to prefer 'levelling up' to 'levelling down' highlights the tensions between pursuit of our common ends and pursuit of equality, even when we have good reason to pursue both (Clayton and Williams 2002). Levelling up means that no one suffers from our efforts to improve the welfare of the disadvantaged, and is therefore Pareto-improving as compared to the status quo. However, raising up the bottom may do little to 'close the gap' in power, wealth, income, and status between the advantaged and the disadvantaged, although 'levelling down' generally implies a loss of collective wellbeing, and is therefore Pareto-suboptimal.

The fairness argument for compulsory voting, then, is difficult to square with democratic politics and morality. Some of these reasons reflect the difficulty of reconciling claims about the common good, or our shared interests, with egalitarian politics. Others reflect the difficulty of linking a democratic conception of the common good to the idea that not voting is free-riding, and that high-turnout is especially desirable. As such, the difficulties with the fairness case for $\mathrm{CV}$ illuminate the moral and political dilemmas of democratic politics and voting. 
We have seen that it is difficult to justify $\mathrm{CV}$ on consequentialist grounds or deontological ones. It may therefore seem that we should abandon the effort to justify CV on explicitly moral or political grounds and, instead, look to epistemic ones in future - on the grounds that our interests in truth are distinct from, even if they may overlap with, our interests in morality. Some people suppose that democracy can, or should, be justified epistemically, based on the way that democratic institutions and practices improve the quality of political decisions, or 'track truth' in political matters (Talisse 2007; Misak 2008; Estlund 2008). However, you do not have to adopt such views to accept that democratic government has an important information-aggregating aspect, and to wonder, with Maskivker (2016), whether that informational aspect of democracy might generate compelling arguments for CV where distinctively moral or political ones fail.

However, it is unlikely that we can get such arguments to work. As we have seen, there is no democratic case for compulsory voting on the grounds that it is in people's interests to vote (even if it is), as this argument only works if the disadvantaged vote their self-interest. And we have just seen that neither high-turnout nor the common good are able to save the fairness case for $\mathrm{CV}$. It is unlikely, therefore, that people have a duty to provide information about their beliefs, interests, preferences, circumstances by voting, especially given that survey-research, academic research, politically-motivated research, citizen protests and other communicative activities provide ways for eliciting, collecting and using politically relevant information. Indeed, it is unclear how well voting reveals people's preferences (Hamlin and Jennings 2011) and, because there is usually more than one morally permissible way for voters to vote, it is unlikely that democratic elections will, or should, provide a consistent electoral 'message' to anyone. Hence, the reasons for rejecting Lijphart's arguments for compulsory voting suggest that epistemic arguments for compulsion are unlikely to be democratic either. This is not because epistemic democracy is an oxymoron - as Hill (2016, 
8) implies, when referencing Saffon and Urbinati (2013) - simply that it is far harder to justify CV on democratic grounds than she believes.

\section{Should Countries with CV abandon it?}

We have examined arguments for $\mathrm{CV}$ that purport to show that all democracies should adopt CV. However, their failure does not mean that CV may not sometimes be justified because it makes democratic government possible in circumstances where violent conflict is a real possibility, or in cases where democracies face difficult historical, geographical or political situations.

Compulsory voting (especially with compulsory registration) helps to stabilise electoral turnout, and therefore to predict more accurately the likely effects of different electoral rules. It may therefore be a helpful device during transitions to democratic government, enabling political minorities to ensure that electoral arrangements adequately protect their interests, and reassuring political majorities that the risks of democratic politics are worth taking. It is possible that very high rates of turnout may also be necessary in order to construct a system of proportional representation that adequately reflects the profound social divisions within a country, or that enables it to cope with a combination of great size and diverse geographical and economic interests.

It is hard to know how powerful such context-specific arguments for CV might be - or others like them. ${ }^{14}$ It is also hard to know what types of CV they would justify in practice, or for what duration. But, with these possibilities in mind, it is clearly premature to maintain that all countries with CV should abandon it even if, by 'abandon', one simply imagines a public 
statement that the relevant electoral law will no longer be enforced - as happened in Belgium. ${ }^{15}$

\section{Conclusion}

The ethics of voting have received relatively little attention from philosophers and political scientists, though they are far more complicated than one might have supposed. As we have seen, it is impossible to draw a sharp line between the principles that might justify adopting or rejecting compulsory voting, and the evaluation of individual and collective behaviour within those rules. Resolving disputes about compulsory voting, therefore, requires us to decide when, if ever, people are morally entitled to vote on sectarian identities and interests, rather than for the 'common good' of their fellow citizens; when, if ever, they are morally entitled to vote on altruistic, rather than self-interested, concerns; and when, if ever, they may vote strategically, rather than sincerely. We do not yet have good answers to these questions. Above all, it is difficult to resolve disputes over the ethics of voting in general, and compulsory voting in particular, without relating the conceptions of rights, duty, freedom and equality involved to those in other areas of moral and political philosophy, and to more empirical work on voting, on comparative public policy and political economy.

As a general rule, legal rights help to protect our interests, whether or not we ever exercise them. That is why it is so important that people have legal rights to vote even if, for conscientious reasons, they may never exercise them (Lever 2009, 225). However, what we can do with our right to vote depends on the behaviour of a great number of people we will never know, and whose interests may be quite different from our own. It is therefore hard to see what difference it makes whether or not we exercise our right to vote. A great deal, 
presumably, depends on who we are, how our interests differ from those of other people, and whether the rules of electoral competition counteract, or exacerbate, the conflicts of power and interest in our society.

Consequentialist arguments for and against compulsory voting, therefore, are likely to be persuasive only where they capture the specific structure and dynamics of a particular political setting, being too speculative or dependent on controversial assumptions to be persuasive otherwise. Non-consequentialist concerns with democracy, freedom, equality, rights and duties are, therefore, likely to do much of the work in a philosophical evaluation of compulsory voting, and the ethics of voting more generally. As we have seen, these generally tell against compulsory voting as an expression of democratic values, interests and duties, except in very particular circumstances. However, it is not easy to characterise 'voluntary voting' - or the alternative(s) to compulsory voting. Legal coercion is not the only obstacle to people's freedom, and democrats may differ in the importance that they attach to the others (Miller 2006). There is, therefore, much work to do in clarifying what forms of freedom and equality are necessary for democratic voting, and for the institutions, laws and customs which protect and define it.

\section{References}

Ballinger, Chris. 2006. "Compulsory Turnout: A Solution to Disengagement?" In Democracy and Voting, edited by Chris Ballinger, 5-22. London: Hansard Society Democracy Series.

Beerbohm, Eric. 2012. In Our Name: The Ethics of Democracy. Princeton: Princeton University Press.

Birch, Sarah. 2009a. "The case for Compulsory Voting." Public Policy Research 16 (1):2127. 
Birch, Sarah. 2009b. Full Participation. A Comparative Study of Compulsory Voting. Manchester: Manchester University Press.

Blais, André. 2000. To Vote or Not to Vote; The Merits and Limitations of Rational Choice Theory. Pittsburgh: University of Pittsburgh Press.

Brennan, Jason. 2009. "Polluting The Polls: When Citizens Should Not Vote." Australasian Journal of Philosophy 87 (4):535-549.

Brennan, Jason. 2016. "The Ethics and Rationality of Voting", The Stanford Encyclopedia of Philosophy (Winter 2016 Edition), Edward N. Zalta (ed.), URL = <https://plato.stanford.edu/archives/win2016/entries/voting/>.

Brennan, Jason, Hill, Lisa. 2014. Compulsory Voting: For and Against. New York: Cambridge University Press.

Caplan, Bryan. 2008. The Myth of the Rational Voter: Why Democracies Choose Bad Policies. Princeton: Princeton University Press.

Clayton, Matthew, Williams, Andrew (eds.). 2002. The Ideal of Equality. Basingstoke: Palgrave Macmillan.

Cohen, Gerald Allan. 1997. "Where the Action is: On the Site of Distributive Justice." Philosophy and Public Affairs 26 (1):3-30.

Cohen, Gerald Allan. 2002. "The Pareto Argument for Inequality." In The Ideal of Equality, edited by Matthew Clayton and Andrew Williams, 162-181. Basingstoke: Palgrave Macmillan.

Cohen, Joshua. 1996. "Procedure and Substance in Deliberative Democracy." In Democracy and Difference: Contesting the Boundaries of the Political, edited by Seyla Benhabib, 95119. Princeton: Princeton University Press. 
Dahl, Robert. 1989. Democracy and Its Critics. New Haven: Yale University Press.

Engelen, Bart. 2007. "Why Compulsory Voting Can Enhance Democracy." Acta Politica, 42 (1):23-39.

Engelen, Bart. 2009. "Why Liberals Can Favour Compulsory Attendance." Politics 29 (3):218-222.

Estlund, David. 2008. Democratic Authority: A Philosophical Framework. Princeton: Princeton University Press.

Gratschew, Maria. 2004. "Compulsory Voting in Western Europe." In Voter Turnout in Western Europe Since 1945: A Regional Report, edited by Rafael Lopez Pintor and Maria Gratschew, 25-31. Stockholm: International IDEA.

Hamlin, Alan, Jennings, Colin. 2011. "Expressive Political Behaviour: Foundations, Scope and Implications." British Journal of Political Science 41 (3):645-670.

Hanna, Nathan. 2009. "An Argument for Voting Abstention." Public Affairs Quarterly 23 (4):275-286.

Hill, Lisa. 2002. "Compulsory Voting: Residual Problems and Potential Solutions." Australian Journal of Political Science 37 (3):437-455.

Hill, Lisa. 2006. "Low Voter Turnout in the United States. Is Compulsory Voting a Viable Solution?" Journal of Theoretical Politics 18 (2):207-232.

Hill, Lisa. 2010. "On the Justifiability of Compulsory Voting: Reply to Lever." British Journal of Political Science 40 (4):917-923. 
Hill, Lisa. 2016. "Voting turnout, equality, liberty and representation: epistemic versus procedural democracy." Critical Review of International Social and Political Philosophy 19 (3):283-300.

Keaney, Emily, Rogers, Ben. 2006. "A Citizen's Duty: Voter inequality and the case for compulsory turnout." Institute for Public Policy Research.

Kenworthy, Lane, Pontusson, Jonas. 2005. "Rising inequality and the politics of redistribution in affluent countries." Perspectives on Politics 3 (3):449-471.

Lacroix, Justine. 2007. "A Liberal Defence of Compulsory Voting." Politics 27 (3):190-195.

Lever, Annabelle. 2008. "A Liberal Defence of Compulsory Voting’: Some Reasons for Scepticism." Politics 28 (1):61-64.

Lever, Annabelle. 2009. "Liberalism, Democracy and the Ethics of Voting." Politics 29 (3):223-227.

Lever, Annabelle. 2010a. "Democracy and Voting: A Response to Lisa Hill." British Journal of Political Science 40 (4):925-929.

Lever, Annabelle. 2010b. "Compulsory Voting: A Critical Perspective." British Journal of Political Science 40 (4):897-915.

Lever, Annabelle. 2017. "Must we Vote for the Common Good?" In Ethics in Politics. The Rights and Obligations of Individual Political Agents, edited by Emily Crookston, David Killoren and Jonathan Trerise, 145-156. New York: Routledge.

Lijphart, Arend. 1997. "Unequal Participation: Democracy's Unresolved Dilemma." American Political Science Review 91 (1):1-14. 
Lopez-Guerra, Claudio. 2014. Democracy and Disenfranchisement: The Morality of Electoral Exclusions. Oxford: Oxford University Press.

Mansbridge, Jane. 1999. "Should Blacks Represent Blacks and Women Represent Women? A Contingent 'Yes'." Journal of Politics 61 (3): 628-657.

Margetts, Helen. 2006. "Citizens Cannot Be Compelled to Engage with Political Organisations." In Democracy and Voting, edited by Chris Ballinger, 29-35. London: Hansard Society Democracy Series.

Maring, Luke. 2016. "Why Does the Excellent Citizen Vote?" Journal of Political Philosophy 24 (2):245-257.

Maskivker, Julie. 2016. "An Epistemic Justification for the Obligation to Vote." Critical Review 28 (2): 224-247.

Miller, David (ed.). 2006. The Liberty Reader. Edinburgh: Edinburgh University Press.

Misak, Cheryl. 2008. "A Culture of Justification: The Pragmatist's Epistemic Argument for Democracy." Episteme: A Journal of Social Epistemology 5 (1):94-105.

Olson, Mancur. 1965. The Logic of Collective Action. Cambridge, MA: Harvard University Press.

Phillips, Anne. 1995. The Politics of Presence. Oxford: Oxford University Press.

Rawls, John. 1971 [1999]. A Theory of Justice. [revised ed.] Cambridge, MA: Belknap Press.

Riker, William. 1982. Liberalism Against Populism: A Confrontation between the Theory of Democracy and the Theory of Social Choice. San Francisco: W. H. Freeman and Company. 
Rovensky, Jan. 2008. "Voting: A Citizen's right, or Duty? The Case Against Compulsory Voting." Unpublished doctoral dissertation, Faculty of Political Science, LUISS Guido Carli, Rome.

Saffon, Maria Paula, Urbinati, Nadia. 2013. "Procedural democracy, the bulwark of equal liberty." Political Theory 41 (3):441-481.

Satz, Debra. 2010. Why Some Things Should Not Be For Sale: The Moral Limits of Markets. Oxford: Oxford University Press.

Saunders, Ben. 2010. "Democracy, Political Equality, and Majority Rule." Ethics 121 (1):148-177.

Shelby, Tommie. 2007. "Justice, Deviance, and the Dark Ghetto." Philosophy and Public Affairs 35 (2):126-160.

Stone, Peter. 2011. The Luck of the Draw. The Role of Lotteries in Decision Making. Oxford: Oxford University Press.

Talisse, Robert. 2007. A Pragmatist Philosophy of Democracy. London: Routledge.

Walzer, Michael. 1983. Spheres of Justice: A Defense of Pluralism and Equality. New York: Basic Books.

Weale, Albert. 1999. Democracy. Basingstoke: Macmillan Press.

Weber, Max. 1919 [1946]. "Politics as a Vocation." In From Max Weber: Essays in Sociology, edited by H.H. Gerth and C. Wright Mills, 77-128. New York: Oxford University Press.

Wertheimer, Alan. 1975. "In Defense of Compulsory Voting." In Participation in Politics, edited by Roland Pennock and John Chapman, 276-296. New York: Lieber-Atherton. 
Williams, Melissa. 1998. Voice, Trust and Memory: Marginalised Groups and the Failure of Liberal Representation. Princeton: Princeton University Press.

Young, Iris Marion. 1990. Justice and the Politics of Difference. Princeton: Princeton University Press.

\section{Acknowledgements}

We would like to thank Alan Hamlin for his thoughtful comments on an earlier draft of this chapter, and Yoann Della Croce and Melis Akdag for research help. We are also grateful to the Fonds National Suisse for funding the research on which this paper depends as part of their grant for a project on democratic ethics.

\footnotetext{
${ }^{1}$ This point has obvious affinities with G.A. Cohen's (1997) concern about the sharp distinction that Rawls (1971, 6-10) wished to draw between people's willingness to support and abide by the rules required for social justice and the way that they make personal decisions within those rules.

${ }^{2}$ http://www.lemonde.fr/idees/article/2011/12/14/vive-le-vote-obligatoire_1618117_3232.html

${ }^{3}$ https://www.theguardian.com/us-news/2016/apr/10/barack-obama-praises-australias-mandatory-voting-rules.

${ }^{4}$ https://www.theguardian.com/politics/2005/jul/04/uk.voterapathy.

5 Lacroix endorses the ECHR view that there is no violation of conscience when people are forced to vote, because they can always cast a blank vote. (Lacroix, 2007, 193). On those grounds, being forced to attend Church would not violate my conscience, as long as I do not have to pray. This is clearly not a satisfactory interpretation of freedom of conscience.

${ }^{6}$ However, morally they may be different (see Hanna 2009)

${ }^{7}$ The argument here has affinities with GA Cohen's (2002).

${ }^{8}$ Unfortunately, Hill appears to assume that politicians are interested only in whether people are likely to vote, rather than whether they are likely to vote for them. (Hill 2016, 294) She also confuses a discussion by Kenworthy and Pontusson (2005, 456-459) of the 'Melzer-Richard model of the relationship between market
} 
inequality and redistribution' with the claim that in and of itself high turnout increases egalitarian social policies by government. Kenworthy and Pontusson's article is concerned with the best way to measure 'market inequality'. It has ' $n o$ interest in, and nothing to say about, voting', as Pontusson confirmed in a private conversation.

${ }^{9}$ For example, Nathan Hanna (2009) believes that people have a duty to abstain, rather than to vote, given current injustice.

${ }^{10}$ If this point is correct, one of the difficulties with arguments for lotteries instead of elections as a way of determining who should govern, is that they, too, tend to assume the cooperative aspects of democracy are more important than the competitive ones. However, for interesting efforts to get round these problems, and to combine lotteries with many of the main features of democratic elections, see Saunders (2010), Lopez-Guerra (2014) and Brennan (in Brennan and Hill 2014).

${ }^{11}$ Not all moral wrongs are violations of rights, as we see in the case of ingratitude, unkindness and selfishness. 12 For figures from the last US election, see http://www.rasmussenreports.com/public content/political_commentary/commentary by kyle kondik/incumbe nt_reelection_rates_higher_than_average_in_2016. As stated in the article, "393 of 435 House representatives, 29 of 34 senators, and five of 12 governors sought reelection (several of the governors were prohibited from seeking another term)". For interesting discussions of French abstention, relative to the perceived importance of the election, see Didier Maus (2015) at http://www.partiradical.net/files/parti_radical/contenu/Actualites/Note257.pdf.

${ }^{13}$ This is a reason why deontological reasons to participate in politics, as well as virtue ethics may be more important factors in political participation - especially over the long-term - as compared to more straightforwardly consequentialist ones.

${ }^{14}$ Mark N. Franklin, 'You want to vote where everyone knows your name: anonymity, expressive engagement and turnout among young adults', unpublished paper, 2006, available online at http://www.lse.ac.uk/government/research/resgroups/PSPE/pdf/Franklin.pdf

${ }^{15}$ http://www.nrc.nl/buitenland/article2263399.ece/Belgie_vervolgt_niet-stemmers_niet_meer- .Thanks to Dr. Alex Voorhoeve for the link. 